UDC 11:75

Lucio GIULIODORI,

Elena NOTINA

\title{
THE VISION AND THE ENIGMA: NIETZSCHE'S AURA IN DE CHIRICO’S ART
}

\begin{abstract}
Giorgio De Chirico definitely stands out as a peculiar character of the Italian Novecento and his art ties directly with Nietzsche's philosophy whose eternal questions paved the way to his "immanent metaphysics" which is typified and pervaded by ever-present melancholia brought about by a heightened awareness of the death of God.

Grappling with "the world seen for the first time" De Chirico's narrative does not depict reality rather its ghost, the latter is seen by dint of revelations and hallucinations.

This paper sheds light onto some significant kinships between the two characters as not only philosophical concerns are vital but illness too. The philosopher suffered since his very childhood from severe migraine and then from a psychiatric illness with depression while the painter unknowingly suffered from migraine aura. This ailment, affecting the fragile border amid perceived reality and hallucinated reality, turned out to be a remarkable source of inspiration which boosted the visions and the enigmas the artist was entwined with.

Overall, Nietzsche ushered in a picture of the world that De Chirico has wholeheartedly shared, however, in the light of his disorder, the empathy went even further, and this is the noteworthy aspect this paper aims at underscoring.

Keywords: Giorgio De Chirico, Friedrich Nietzsche, avant-gardes, metaphysical art, Italian studies, Italian art, philosophy of art, neuroaesthetics, illness.

Introduction

Shortly after De Chirico's father died (1905), his mom Gemma decided to move to Germany looking at this country as an ideal place for her children's education. Her move turned out to be totally farsighted.

In 1907, at the age of 18, Giorgio De Chirico entered the Academy of Fine arts in Munich. This was indeed an essential chapter of his life as from now on, and De Chirico started to soak up

the intense artistic atmosphere of one of the most vibrant European capitals at his time. The process of cultural assimilation affected not only the artistic sphere - his early works are deeply influenced by Böcklin, let us think of The enigma of the Oracle (1909) $)^{1}$ - Nietzsche and Schopenhau-

1 "The pensive figure wrapped in a long cloak seen in a rear view, fully in the Romantic tradition of contemplative figures seen from behind" - let us think of Caspar Friedrich's Wanderer - "is cited almost literally from Böcklin's Odysseus and Calypso of 1882. De Chirico was fascinated during this period by
\end{abstract}


er soon became strong pillars of his picture of the world, a world painted with their enthralling philosophies.

As J. M. Faerna (1995) outlines:

"This distinctive grounding was markedly different from that received by most other young French and Italian artists of the period, whose lessons came largely from the poetic Tradition of Romanticism - Charles Baudelaire, Arthur Rimbaud and Stéphane Mallarmé. This difference helps to explain the singularity of De Chirico's work, which his contemporaries did not always understand. It also provides a clue to his method of painting, which was first intellectual and the pictorial' (p. 7).

Even though De Chirico was a welleducated painter whose interests were wide, Nietzsche certainly stands out as the main source of his inspiration, the foundation of his aim, both as a painter and as a human being. As Dori Gilinski (2013) asserts:

"It would be a rather grand claim that the 'meaning' of de Chirico's Metaphysical works could be deciphered with the guidance of Nietzsche's writings. Does the relationship of influence between the philosopher and the artist suggest this is possible? De Chirico aestheticises Nietzsche's ideas, yet his pre-1915 works are hardly transcriptions in image form. Indeed, De Chirico's genius lies not merely in interpreting Nietzsche's philosophies but in conjuring a mysterious atmosphere, a forlorn mood, an inexplicable sensation that

Homer's account of the wanderings of the Greek hero Odysseus, who, as the embodiment of a traveler with an uncertain destiny, became another figure of identification in his own life history. Böcklin's pensive Ulysses, yearning for home, becomes in De Chirico's painting a thinker contemplating the enigmas of the world and the mystery of his own existence. The oracle, voice of fate, is present in the shape of the marble head of a statue concealed behind a curtain" (Holzheny, 2017, p. 14). may be the very 'revelation', pictorially of course, that readers of Nietzsche are looking for in text" (p. 11).

First of all, De Chirico shares with Nietzsche the love for ancient Greece and not only because he was born in that country. In the early twentieth century among artists and men of culture, the love for classics, Greek myths, in particular, was widely spread if not even a must ${ }^{2}$. Ancient Greek references in De Chirico's paintings are persistent, let us think of Hector and Andromache, The song of love, Furniture and rocks in a room and Strange travellers just to name a few.

M. Holzhey (2017), referring to De Chirico's famous portrait, summarises the matter:

"The pose he strikes in his self-portrait of 1911 is a direct citation of Nietzsche's own portrait photograph. De Chirico saw Nietzsche not only as a guideline but also as a figure of identification [...] With Nietzsche De Chirico shared not only his love of the enigma but also his fascination with the world of classical mythology. Both the Latin quotation beneath the programmatic self-portrait and the eye devoid of a pupil make reference to the blind seer of antiquity. We will encounter the notion of outer blindness again and again in De Chirico's ouvre. Blind to the present, the eye is not fixed on outward form but sees the inner or future shape of things. The Metaphysical artist therefore assumes a prophetic ability to turn his gaze upon the unfamiliar aspect of things" (p. 8.).

Nietzsche is defined by De Chirico (1999) as "the most profound of all poets" and the paint-

2 Renato Miracco (2013) speaks about "the need felt by $20^{\text {th }}$ century art to go back through past ages and civilizations, attempting to retrieve a primordial gynaeceum, the origin, the matrix, and to develop a monumental representation that will impress itself onto the collective mind and constitute an indelible reference image", (p. 13). 
ing The Delights of the Poet of 1913 is most likely dedicated to him $^{3}$. Writing to his friend Fritz Gartz, the Master affirms: "I am the only man who has understood Nietzsche, all my works prove it" (p. 422). In another letter he clarifies:

"A new air has now flooded my soul - a new song I've heard - and the whole world now appears to me completely changed the afternoon Autumn has arrived stretched shadows, clear air, clear sky - in a word Zarathustra has arrived, did you understand me???"(Dottori, 2019, p. 98, my translation).

In the famous chapter, The vision and the enigma - this title alone could precisely describe the whole art of De Chirico - Zarathustra, talking to the dwarf, declares:

"See this gateway, dwarf!" I continued. "It has two faces. Two paths come together here; no one has yet walked them to the end. This long lane back: it lasts an eternity. And that long lane outward - that is another eternity.

They contradict each other, these paths; they blatantly offend each other and here at this gateway is where they come together. The name of the gateway is inscribed at the top: 'Moment"' (Nietzsche, 2006, p. 225).

The timeless and motionless moment finds its perfect balance both in the Nietzschean eter-

3 "The first work to exhibit the typical characteristics of these Italian squares with their enigmatic mood is The Delights of the Poet: a wide, empty piazza bordered by shadowy arcades leading back into the depths; a high horizon with a locomotive travelling across it; a railway station; a sky of vibrant green; long, slanting shadows; in the square a solitary figure sunk in thought.

The motif of the fountain, already familiar from earlier compositions such as The enigma of the Hour, is borrowed from Nietzsche. According to Zarathustra's "Night Song": "Tis night: now do all gushing fountains speak louder. And my soul also is a gushing fountain" (Holzhey, 2017, p. 24). nal afternoon ${ }^{4}$ and in the afternoon that stretches the uncanny shadows populating De Chirico's squares, filled with Schopenhauerian melancholy, mirrors of inner kaleidoscopic experiences. Not a metaphysics of beyond rather a row metaphysics overtly entwined with the empirical facets, embedded in the here and now, made of stillness mightily bewildering.

It was this all-important conclusion that De Chirico took from Nietzsche. Pittura Metafisica sought the enigmatic quality of earthly phenomena not in some other dimension, but within the things of this world: "We metaphysicians have sanctified the real", he wrote in 1919. De Chirico, with excellent penetration, recognised this aspect in Nietzsche, who did not limit himself to the destruction of an idealistic truth but prepared the ground for a new poetics (Holzhey, 2017, p. 15).

De Chirico's aim lies into exercising the eye, like the rest of the senses, in order to realise how metaphysics is rooted in the daily world of experience; only once this goal is attained it is possible to penetrate the enigma of the moment, to have a vision of it. To this regard, the Italian painter reminds of Lev Šestov's "second sight", a rare ability necessary to go beyond the analytical perception of reality, i.e. the ordinary lowbrow perception, in order to glimpse what lies beyond the realm's layers of meanings.

However, this again refers to an elitist, "esoteric" matter as the majority of people - De Chirico seems to suggest - are not able to get that far, as long as they keep their eyes stuck to the traditional arrow of time that hides the moment of the enigma under the linear sequence of past,

\footnotetext{
4 "For Zarathustra the "great noontide" meant high point and turning point, the experience of eternity and the stopping of time, a new perception of the world" (Holzhey, 2017, p. 37).
} 
present and future ${ }^{5}$. Zarathustra's teachings instead, transcending the discontinuity of that temporal tryptic, invites the initiate to travel not towards something but into something, something mysterious, as mysterious as "This Moment".

The Master, on a number of occasions, unequivocally underscores the elitist essence of Metaphysical Art, even strongly worded, in fullNietzsche style. To this regard, in a letter to Gartz, for example, he wrote:

"When I told you my paintings are profound, you must have thought they were gigantic compositions with many naked figures trying to overcome something, like those painted by Michelangelo, the stupidest of all painters. No, my dear friend, it is completely another matter - profoundness as I understand it and as Nietzsche understood it, is found elsewhere than where it has been searched for until now. My paintings are small, the biggest $50-70 \mathrm{~cm}$, but each of them is an enigma, each contains a poem, an atmosphere [Stimmung] that cannot be found in any other painting. When I exhibit them... it will be a revelation for the whole world" (Ross, 1999, p. 422).

In his book Commedia sulla materia pittorica, he is as much direct:

"The imbecile man, the non-metaphysic, is instinctively led towards the appearance of mass and height, towards a kind of architectural Wagnerism. Affair of innocence; they are men who do not know the terrible lines and angles; they are worn versus the infinite and it is here that their limited psyche is revealed [...]. However, we who know the signs of the metaphysical alphabet know which joys and pains are en-

As Manlio Sgalambro states: “A philosophical work must be like chamber music for the initiate and it must remain an enigma for the common people" (Sgalambro, 1991, p. 106). closed within a portico, the corner of a road or even in a room, on the surface of a table, between the sides of a box.

The limits of these signs constitute for us a kind of moral and aesthetic code of representations and moreover, we, with clairvoyance, construct in painting a new metaphysical psychology of things" (De Chirico \& Far, 2002, p. 32).

"Clairvoyance" is a key-word here as De Chirico really thought to possess some kind of magic powers, this was due to the hallucinations he suffered from which allowed him to see things other people could not see - this topic will be discussed in the last paragraph. For now, suffice to highlight that in De Chirico, the esoteric elements, totally absent Nietzsche, shouldn't be underestimated as they fuel his Weltanschaunng significantly.

\section{An Empty Space of Non-Sense}

Riccardo Dottori (2006) understands metaphysical painting, as carried out by de Chirico, as "the transmutation of a philosophical tradition into an art form" (p. 203).

To this regard, Dori Gilinski (2006) states:

"De Chirico did not seek to paint as a painter, but rather as a philosopher. The very description of his works as 'metaphysical' grants them a peculiar theoretical bent by virtue of the obvious connection to the branch of philosophy, which is primarily concerned with the nature of existence in the world, with what is. Without a doubt, de Chirico's work, when compared with his artistic contemporaries, shows a heightened awareness of these 'eternal' questions, underscored by a peculiar uncertainty in respect to whether answers to such questions can ever be achieved. Once again, the influence of 
Nietzsche is ever-present for it is he and

Schopenhauer who "were the first to teach

me the non-sense of life and how such non-

sense could be transmuted in art' (p. 203).

Nietzsche not only rejects the possibility of universal truth but calls into question its value: "Granted that we want the truth: Why not rather untruth? And uncertainty? Even ignorance? The problem of the value of truth presented itself before us" (Nietzsche, 2008, p. 9). If not the truth, then the enigma.

"What should I love, if not the enigma of things?" This is what is written under his first self-portrait in 1911, and this is how he sees $^{6}$ reality: as an enigma. In the wake of Nietzsche, no ultimate truth could substantiate reality for there is no meaning at all out there. If Nietzsche refused metaphysics in its traditional meaning, so De Chirico did: beyond this world, there is no God, there is no truth, there is no sense.

Contrariwise, metaphysics, in its new dechirichian meaning, deals with this reality, the meaning of things, if there is one, is immanent to the things themselves, this is why De Chirico's main characters are things: objects, buildings, shadows, squares, mannequins etc.

6 "Seeing" is a crucial ability in De Chirico, in his Commedia dell'arte moderna, the painter targets veristi (realists) painters, guilty of not being able "to see": "In Italy, there is a strong tendency among painters to entrench themselves behind the aegis of the word "verismo"; [...] Those who do not know them, could imagine them as men in love with nature, spending their days in the observation and continuous study of the sky, the earth, the waters, men, plant, animals. But alas! This is not the case. They are simply mediocre artists. The gods have denied them not only genius but talent too and therefore all those virtues that are linked to talent and genius such as: creativity, heroic sense, feeling, acumen, lyricism, memory, faculty of assimilation and of enslave the assimilated to one's personality. They, on the contrary, never observe nature and, if they look at it they do it with the banal man's eyes who looks without seeing. They are not equipped with the eyes of the observing artist, able to guess and remember". (De Chirico \& Far, 2002, p. 36, my translation).
In the world painted by De Chirico, men (both in their psyche and body) and space are intertwined, insofar as everything exists by dint of this enigmatic, metaphysical alchemy, a sort of interconnectedness of all things whose reason remains unknown though. In this unitary dimension, the numerous arcades painted by the Master, stand out as an occult open passage towards the mystery, symbolised by the omnipresent shadows.

Probably the most fundamental teaching De Chirico received from Nietzsche is the impossibility of finding an ultimate and universal truth. The consequence is a kind of immanent metaphysics, which at once includes the subject's psychic space and the external space as if they were the same thing, so deep is the connection that this metaphysics can guarantee.

"The non-sense of the world hides a more in-depth and yet more indecipherable sense, "metaphysical", which cannot be described, but only revealed by an image that the artist has the power to fix" (Calvesi \& Mori, 2007, p. 5).

If Nietzsche especially in Human, all too human, set the special farewell from the western philosophical tradition which claimed to reach the truths of being, the truth of universal knowledge, De Chirico with his art, experienced a similar separation. His mannequins, as humanised emblems of melancholy, embody it: they are caught in a moment of metamorphosis: they veer towards unknown dimensions of being, categorically enigmatic, far away from definite, ultimate, philosophical (metaphysical in the traditional meaning) definition of truths.

The end of traditional metaphysics can be traced back to the famous Nietzschean exclamation: "God is dead!". As Martin Heidegger (1984) states: "God is the term to designate the world of ideas and ideals [...] Thus the expres- 
sion "God is dead" means that the ultra-sensitive world is without real force, it does not dispense life at all. [...] If God, as an ultra sensible cause and as the end of every reality, is dead, if the world of ideas that is ultra-sensitive has lost its normative force, and above all its strength of awakening and elevation, nothing remains to which man can stick and according to which he can regulate himself. [...] "God is dead" is the realisation that this nothing is rampant. "Nothing" means here: the absence of an ultrasensitive and binding world" (p. 356, my translation).

This deafening nothingness brings about an unusual condition of multiple sentiments, only apparently antithetical, from the one hand solitude and melancholy, from the other hand power (in De Chirico even magic) and fullness. Those sentiments are experienced by Nietzsche and De Chirico, in a different though very similar way.

Nietzsche lives this condition through a sort of fullness, incarnated by Zarathustra who completely rejected transcendence and by doing this he says yes to life, recovering in his earthly dimension. It is about a subject who has a body made of instincts and impulses which expresses the rebirth and liberation of the congenital, rediscovered, Dionysian element.

This is the "the meaning of the earth", embodied by the Übermensh as Zarathustra announced it, because by rejecting once and for all any metaphysical temptation, he declares his fidelity to the earth, by doing that, he recovers a love for life and the world.

In the same way De Chirico, in 1932, as an extraordinary solitary man, as he felt, begins a new artistic and existential path, in which he mainly displays nudes, portraits and still life, then no longer "anonymous" and mysterious mannequins. Those though, for this study, are considerably important, that is why their role in De Chirico's output, will be discussed in the next paragraph.

\section{Mannequins: An Attempt to Overcome Humanity}

The death of God implies that no finality can be ascribed to either the world or human action, the first main consequence is sufferance: man has no more values to follow and feels inevitably lost in his way. He can but fall into a state of existential melancholy. This sentiment is repeatedly depicted in De Chirico's works, let us think of the painting Melancholia (1916) where this topic is the primary subject matter.

Mannequins perfectly embody this sentiment.

They seem the Master's alter ego: they are devoid of eyes and mouths as they see the world with a kind of "third", inner eye (a further esoteric reference), obviously more powerful than the human one, as Gerard Legrand points out to us, "cabalistic tracery occasionally appears on manuscripts, and the mannequins display on their foreheads strange circular stigmata (presumably derived from the conventional sign for infinity), endowing these earless, eyelidless beings with such features as fish gills, or the single eye of the ancient Cyclops" (Legrand, 1979, p. 47).

Furthermore, they lack a mouth as they do not need to speak, at least in everyone's language. The absence of the mouth symbolises what in De Chirico is predominant: silence. They speak silence because the world they inhabit is a silent, mute, melancholic world and in order to describe that world they do not need to speak whatsoever, they think though. The bulky geometrical constructions which they always bear, relate to a noetic architecture, an endeavour on 
the level of thought.

Alberto Savinio, with his novel Chants de mi mort whose main character was a faceless man, deeply inspired his brother Giorgio De Chirico who starting from 1917 steadily began to paint mannequins.

However, behind this choice, we cannot but spot, again, a clear Nietzschean echo: the dummies, de facto, replacing human beings, symbolise an attempt to overcome humanity, a work in progress towards the Übermensch probably.

However, taking everything into account, I do think one more layer of meaning could be spotted.

We should bear in mind De Chirico, even if for a short time, was a soldier, as such he experienced the brutality of war, he suffered the consequences of it, precisely at the Hospital of Ferrara, the "Villa of enigmas". Therefore the dummy could also symbolise man facing something more significant than him, out of his control: war indeed. This man is physically and psychologically harmed, helpless and powerless, at the mercy of events. Such a man is in the throes of a kind of dehumanising effect, in so far as he is living in a world ruled by madness, rather than rationality.

This interpretation is abetted by the famous work Hector and Andromache, where a soldier, a dummy, is hugging his beloved woman as he is about to leave her, setting off for war. As we know, De Chirico grabs the Greek myths with both hands, and in Homer's Iliad, Hector is forced to leave his beloved Andromache, going off to war.

As Magdalena Holzhey (2017) highlights:

"De Chirico developed the motif of the mannequin in conjunction with Apollinaire and Savinio. The human substitute without face or voice is blind like the seers of antiquity and equally gifted with the power of prophecy. The mannequin is the alter ego of the artist: the blackboard records stations along De Chirico's artistic journey" (p. 40). "The mannequin, in conclusion, represents the achieved figure of his personality as it "becomes a modern formulation of the blind seer of antiquity, a figure with visionary powers. At the same time, it offers a graphic analogy with the increasing loneliness and alienation of modern man, the dissonance of human existence" (p. 45).

$$
\begin{gathered}
\text { Illness as a Source of } \\
\text { Inspiration }
\end{gathered}
$$

As the master himself points out, the metaphysical aspect of reality can be grasped only in rare seconds, "extraordinary moments which transcend the innocence and distraction of ordinary men" (De Chirico \& Far, 2002, p. 26), this is because "psychologically speaking, to discover something mysterious in objects is a symptom of cerebral abnormality related to certain kinds of insanity" (De Chirico \& Far , 2002, p. 26). The real madness, as the Master underlines, “doesn't appear to everybody, but it will always be and keep gesticulate and wave behind the matter's screen" (De Chirico \& Far, 2002, p. 26). Massimo Carrà was referring at it as the voice of the eternal, as "the grace that in the beginning was flourishing down here: the terrestrial immortality" (Carrà, 1968, p. 242, my translation).

Madness attracting De Chirico's concerns could also be undoubtedly ascribed to his total love for Nietzsche, a philosopher who indeed went crazy. The famous conversation with a horse took place in Turin in Piazza Carlo Alberto, where an equestrian statue of Carlo Alberto stands. The Pictor Optimus depicted that statue in many of his works and it is not difficult to spot 
a homage to Nietzsche and his madness.

Quite interesting are some affinities between Nietzsche and De Chirico in terms of inspiration and disease. First of all Nietzsche, as well as De Chirico, suffered from migraines, without aura ${ }^{7}$ though.

Elisabeth Forster-Nietzsche writes:

"As I had already said, the illness that embittered my brother's whole life was a migraine. The days of headaches and nausea followed one another, in the best periods, every three, four weeks, but in the worst periods they haunted him almost every week... Sometimes I thought that these attacks were a cruel trick of nature to keep him away from his work, since in those days he could do nothing at all" (Förster Nietzsche, 1990, p. 21).

The second affinity relies on the concept of disease as a real source of inspiration, let us consider Nietzsche's words:

"Once, during the continuous torture my brain gave me for three days accompanied by a painful vomit of mucus, I had an exceptional dialectic lucidity and I was able to think in cold blood and in every particular thing for which, in better health, I do not demonstrate a sufficient ability, a sufficient coldness" (Förster Nietzsche, 1990, p. 21).

Therefore, both Nietzsche and De Chirico conferred high value to their diseases concerning the concept of creativity itself. As for the Italian artist, not only important rather determinant is the value De Chirico always bestowed to his set of diseases, let us mention the day in Piazza Santa Croce, when he had the intuition of Enigma

7 About De Chirico's migraine aura, see my article Paintings and hallucinations: Giorgio De Chirico's aura: https://www.academia.edu/40661295/ Paintings and hallucinations Giorgio De Chirico s aura while about Nietzsche's migraine see: Hemelsoet, D., Hemelsoet, K. \& Devreese D., 2008. d'un pomeriggio d'autunno (1910) and actually, when Metaphysical Art was born. Here's his own words about it:

"On a clear autumn afternoon, I was sitting on a bench in the middle of Piazza Santa Croce in Florence. It certainly wasn't the first time I had seen this square. I had just come out of a long and painful intestinal disease and I was in a state of almost morbid sensitivity. The whole nature, up to the marble of the buildings and fountains, seemed to me convalescing. In the middle of the square stood a statue that represented Dante dressed in a long cloak (...). The statue was in white marble, but time had given it a very pleasant gray tint. The autumn sun, warm and without love, illuminated the statue and the facade of the temple. Then I had a strange impression of seeing everything for the first time. And the composition of my painting came to mind; and every time I looked at it I saw this moment again: however, the moment for me is an enigma, because it is inexplicable. And I also like to call enigma the work inspired by it" (De Chirico, 2008, pp. 649652).

Noteworthy, De Chirico sees a disease in the surrounding reality as well ("the whole nature, up to the marble of the buildings and fountains, seemed to me convalescing"), not only in himself. This lets us understand how sizable in the dechirichian Weltanschauung is the marriage of art and disease.

Ultimately, we need to consider how mesmerising was the theory of the Eternal Recurrence for De Chirico. The painter was "hypnotised" by this concept because of two different reasons, and the first refers to his migraine problems while the second concerns a fascinating belief. 
De Chirico suffered from a very peculiar disease called "migraine aura", and one of this disease's symptoms is déja-vù. In his writings, the Pictor Optimus, repeatedly speaks about dé$j a-v u ̀$ sensations, at times in association with other migraine symptoms. All things considered, it may be pertinent to propose, as Nicola and Podoll (2003) also do, a link between these symptoms and the nietzchean concept. In other words, it could have been precisely these migraine experiences that aroused his interest in this philosophical doctrine.

The second reason, from a critical point of view, is undoubtedly fascinating: De Chirico seems to have genuinely believed in being the reincarnation of Nietzsche.

As discovered by Schmied (1980), this identification is evident from the eloquent title of a work of 1914: Natura morta, Torino 1888. Quite significantly, that year, 1888, was marked both by the birth of the painter in Volos, Greece and by the psychotic crisis of the philosopher in Turin.

According to Baldacci (1997): "De Chirico, as also confirmed by Savinio, believed that Nietzsche's wandering soul had abandoned the philosopher's body to enter his" (p. 37).

Schmied suggests that: "Yes, the identification went so far that it sometimes produced the same symptoms as Nietzsche's disease" (Rubin, Schmied, \& Clair, 1982, pp. 89-107).

Yet this is another aspect that makes this character, a great character, from an artistic, philosophical and psychological point of view ${ }^{8}$.

\footnotetext{
"Now, the artist in and of himself is already a laggard creature because he still plays a game that belongs to youth and childhood; in addition, he is gradually being formed by retrogression into former times. Thus between him and the other men of his period who are the same age a vehement antagonism is finally generated, and a sad end just as, according to the tales of the ancients, both Homer and Aeschy-
}

As it is now fairly clear, De Chirico's specific perception of reality was, albeit partially, influenced by his health disorders, one in particular: the migraine aura and its consequent hallucinations.

\section{Migraine Aura: Beyond Nietzsche}

What is of fundamental importance for our study is to consider how for his whole life De Chirico was never given a diagnosis: he did not know that he suffered from it but experienced the unusual symptoms, the hallucinations ${ }^{9}$. The total ignorance about the illness from which he suffered, is reflected in his writings, from the Memoirs (De Chirico, 2019) to Ebdomero (De Chirico, 2016), where not only his total unconsciousness is evident, but also the consequences that it entailed, especially on the level of personality, altered by an ego magnified by the fact of "seeing what others did not see".

In other words, De Chirico, in the wake of these hallucinations (mistaken for visions and revelations) and in the wake of the identification with Nietzsche, felt himself a sort superior being.

lus finally lived and died in melancholy". (Nietzsche, 2008, pp. 101-102).

9 De Chirico's migraine aura disease was deeply studied by the philosopher Ubaldo Nicola and the neurologist and psychiatrist Klaus Podoll. In their detailed essay L'aura di De Chirico. Aura emicranica e pittura metafisica, they affirm: "In the previous chapter we compared some of De Chirico's works with migraine art. We believe that the extraordinary similarities encountered are probative and corroborate the diagnosis. The migraine origin of metaphysical painting can be said to be demonstrated.

However, this does not mean that De Chirico was aware of it. Not having any diagnosis at his disposal, he always considered his auras not pathological manifestations but disturbing events that he was able to experience and that urgently required an explanation" (Nicola \& Podoll, 2003, p. 56). Moreover, as the two scholars assert, a typical characteristic of these patients is the reticence, i.e. they tend not to talk about it for fear of being mistaken for madmen, however, De Chirico didn't fall into this perspective as we will shortly see. 
As a matter of fact, his pathology was a source of both stress and inspiration.

Many migraine sufferers (artists included) share the view that migraine aura is not only a disease but also a sort of artistic privilege or gift - to this regard Nietzsche (1998) himself stated that "illness can become an energetic stimulant to live, to live more" (p. 20).

"As a matter of fact, migraine aura has all the features to become a source of creativity, even more than dreaming. It takes place without affecting the intellectual lucidity, it repeats itself many times in an almost equal way, it connects in its course to specific emotional states, it shows absurdities that affect the faith in logic and when it is accompanied by paramnesias or visual illusions (for example metamorphopsia, corona phenomenon, autokinesis) gives everyday objects a completely unusual aspect" (Nicola \& Podoll, 2003, p. 131).

It goes without saying that migraine aura qualifies as real support of perception and therefore of a re-description of reality, a revealed reality. One of the most frequent visions for those in the grip of a hallucination produced by migraine aura, are zigzag shapes (abundantly present in works such as $\mathrm{Il}$ rimorso di Oreste and Il ritorno al castello, both from 1969) and geometric figures, the latter plentiful in De Chirico's work.

Elaborate geometric constructions can be primarily found on both the mannequins and the archaeologists (painted and repainted in countless canvases) as if they had the function of reallife support.

The mannequins, adorned on their shoulders or around them, are literally supported by them as if they are their second skeleton. The archaeologists instead, keep them in the abdomen. In both cases, however, they are an integral part of the body, as the hallucinations produced by the migraine aura are an integral part of De Chirico's being.

The perception that the Master had of himself and in general, his personality, are deeply affected by the migraine aura.

In conclusion, De Chirico, already profoundly influenced by Nietzsche, by both his figure and his philosophy, tended to attribute himself some kind of "superpowers". However, the "superman" he somehow felt to be, was not meant only in the Nietzschean sense, but also in an esoteric sense tout court. To this regard, De Chirico pushed himself even beyond Nietzsche.

De Chirico was used to having divinatory or premonitory experiences (or at least they seemed to be as such to him), the most emblematic and famous case is the Portrait of Apollinaire of $1914^{10}$.

Moreover, the Pictor Optimus suffered not only from déjà $v u$ but also from jamais $v u^{11}$ that is, to have the impression that the scene one is witnessing never happened. De Chirico obviously interpreted them as revelations ${ }^{12}$.

To this regard, Nicola and Podoll point out: "He considered his power of access to this particular state of mind as the very essence of his artistic creativity, at least in the metaphysical period" (Nicola \& Podoll, 2003, p. 40).

Furthermore, what to think of the fact that "he claimed to have revelations, premonitory and clairvoyant dreams, to see inside objects as if he had an X-ray view? Alternatively, finally, when he attributed himself very special, if not even paranormal, powers, such as becoming, but only sometimes, phosphorescent?" (Nicola \& Podoll, 2003, p. 40).

10 De Chirico painted him with a Dante profile on whose left temple, a circle similar to a shooting target was depicted. Interestingly, Apollinaire two years later at war was wounded exactly at that point.

11 Both of them are migraine symptoms.

12 Cfr: Raskin \& Appenzeller, 1980. 
De Chirico himself, highlights: "For example, I am phosphorescent. I'm not kidding ... I see my hand in the dark. Moreover, the more time passes, the more I realise that I am an extraordinary man" (Soby, 1995, pp. 244-253). His words leave no shadow of a doubt on the way he perceived himself and on the powers he thought to possess, powers among the most disparate.

In conclusion, according to De Chirico, the world can be perceived according to two specific and antithetical aspects, "a usual one, which we almost always see and which men generally see and the other, the spectral or metaphysical, which can only be seen by rare individuals in moments of clairvoyance and metaphysical abstraction"(De Chirico \& Far, 2002, pp-85-86). He obviously falls into this last and restricted category and loves to remark it repeatedly in his writings and interviews. It should be noted that while many migraine aura patients are reticent in revealing their experiences for fear of being taken for a fool, De Chirico, according to an opposite logic, raises them to superior qualities that distinguish him from the mass, and not only... In doing so, De Chirico went even beyond the philosopher he mostly loved in so far as he went beyond his own perceptions, his abilities to see the world in its inside, to see the world as if it were the first time. All De Chirico's paintings represent the eternal recurrence of this first time, a moment beyond space and time.

\section{REFERENCES}

Baldacci, P. (1997). Giorgio de Chirico. The metaphysical period 1888-1919. Boston-New York-Toronto-London: Little Brown and Co.

Calvesi, M., \& Mori G. (2007). De Chirico. Firenze: Giunti Editore.
Carrà, M. (1968). Metafisica. Milano: Gabriele Mazzotta Editore.

De Chirico, G. (2008). Scritti/1 (1911- 1945). Romanzi e scritti critici e teorici (a cura di A. Cortellessa). Milano: Bompiani.

De Chirico, G. (2016). Ebdòmero. Milano: Abscondita.

De Chirico, G. (2019). Memorie. Milano: La Nave di Teseo.

De Chirico, G., \& Far, I. (2002). Commedia dell'arte moderna. Milano: Abscondit.

Dottori, R. (2006). The Metaphysical Parable in Giorgio de Chirico's Painting. Metafisica, 5-6, 203-213.

Dottori, R. (2019). Dalla poesia di Zarathustra all'estetica metafisica. Retrieved October 26, 2019, from:

https://fondazionedechirico.org/wpcontent/uploads/2019/06/093-116Metafisica-78-R.Dottori-IT.pdf.

Faerna, J. M. (1995). De Chirico. New York: Cameo/Abrams.

Förster Nietzsche, E. (1990). Die Krankheit Friedrichs Nietzsche. Die Zukunft 30.

Gilinski, D. (2013). London: Academia.edu Et quid amabo nisi quod aenigma est: The Influence of Friedrich Nietzsche on Giorgio de Chirico. Retrieved October 26, 2019, from: https://www.academia. edu/21644574/The Influence of Fried rich_Nietzsches_Metaphysics_on_Gior gio de Chiricos Art

Heidegger, M. (1984). Sentieri interrotti (traduz. di P. Chiodi). La Nuova Italia, Firenze.

Hemelsoet, D., Hemelsoet, K., \& Devreese, D. (2008). The Neurological Illness of Friedrich Nietzsche. Acta Neurol Belg. Mar; 108(1), 9-16 Retrieved December 08, 2019, from: https://www.actaneuro 
logica.be/pdfs/2008-1/02-

Hemelsoet\%20et\%20al.pdf.

Holzhey, M. (2017). De Chirico. Köln: Taschen.

Legrand, G. (1979). Giorgio de Chirico. New York: Filipacchi Books.

Miracco, R. (2013). Giorgio De Chirico: myth and archeology. Milano: Silvana Editoriale.

Nicola, U., \& Podoll, K. (2003). L'aura di Giorgio De Chirico. Arte emicrania e pittura metafisica. Sesto san Giovanni: Mimesis.

Nietzsche, F. (1998). Ecce homo. Milano: Adelphi.

Nietzsche, F. (2008). Beyond Good and Evil (H. Zimmern, Trans.). Middlesex: Arc Manor Publishing.

Nietzsche, F. (2008). Human, all too human. London: Wordsworth Editions.

Nietzsche, F. (2006) Thus spoke Zarathustra. A book for all and none (A. del Caro,
Trans.) Chicago: Cambridge University Press.

Raskin, N. H., \& Appenzeller, O. (1980). Migraine: Clinical Aspects. Major Problems in Internal Medicine, 19, 28-83.

Roos, G. (1999). Giorgio De Chirico e Alberto Savinio. Ricordi e documenti (Monaco, Milano, Firenze, 1906-11). Bologna: Bora.

Rubin, W., Schmied, W., \& Clair, J. (1982). Giorgio de Chirico der Metaphysiker. München: Prestel.

Schmied, W. (1980). De Chirico und sein Schatten. Metaphysische und surrealistische Tendenzen in der Kunst des 20. Jahrhunderts. München: Prestel.

Sgalambro, M. (1991). Del pensare breve. Milano: Adelphi.

Soby, J. T. (1995). Giorgio De Chirico. New York: Museum of Modern Art. 